\title{
The Effect Of Stress Towards Performance Of Employees At The Office Of Energy And Mineral Resources In The Makassar City
}

\author{
Nursia \\ The Lecturer of Department of Management \\ STIMI-YAPMIM Makassar, South- Sulawesi, Indonesia \\ Nurlina \\ The Lecturer of Department of Management \\ STIMI-YAPMIM Makassar, South- Sulawesi, Indonesia \\ Anwar Ramli \\ Department of Management, Faculty of Economy \\ State University of Makassar, South Sulawesi, Indonesia
}

\begin{abstract}
The purpose of this study is to determine the effect of stress on the performance of employees at the Office of Energy and Mineral Resources in Makassar. The method used is descriptive survey and explanatory survey method. The type of investigation in this study is causality. The unit of analysis in this study is all employees at the Office of Energy and Mineral Resources in Makassar. The analytical method uses multiple regression with the help of SPSS program. The results showed that individual stressor variables and organizational stressors together have a significant effect on the performance of employees at the Office of Energy and Mineral Resources in Makassar. Then individual stressor variable as the most dominant factor affect the performance of employees at the Office of Energy and Mineral Resources in Makassar.
\end{abstract}

Keywords: Stress, individual stressor, organizational stressor and Employee Performance.

\section{INTRODUCTION}

Human resources is an important asset for the organization, which essentially serves as a driving factor for every activity within an organization. An organization in doing its activities to achieve the desired goals, need good management especially in managing human resources, natural resources and capital.

Labor or employees is one important asset for government agencies, private agencies and companies. Employees have a very important role in the development and progress of government. In actual conditions, employees are human beings who have various problems in their lives, especially stress that will affect the performance and satisfaction of the workforce of the government apparatus.

According to Hasibuan (2010: 204) "stress is a state of tension that affects emotions, thinking processes, and conditions of a person." People who experience stress become more irritable, unable to relax in work or show uncooperative attitude.

Stress is caused by emotional and mental physical fatigue caused by long time involvement with emotionally demanding situations. The process takes place gradually, accumulatively and gradually gets worse. There are many factors driving the cause of stress on employee 
performance, such as communication between employees in a less harmonious government agency, conflicts within the organization, less conducive working conditions, and jobs that exceed the limits of an employee's ability.

The Department of Energy and Mineral Resources of South Sulawesi Province is one of the SKPD (Satuan Kerja Alat Daerah) of South Sulawesi Provincial Government, has the main duty to carry out the affairs of energy and mineral resources based on the principle of decentralization, deconcentration and assistance task. Employees at the Office of ESDM keep trying to improve job satisfaction in order to produce good performance as well. This is indicated by explaining the main tasks of the ESDM ministry, namely the formulation of technical policy in the field of mining, the conduct of mining and energy affairs and public services as well as the development and implementation of other tasks. In carrying out the main task to be achieved the staff must have a good performance in order to produce a good job satisfaction.

Employees are often faced with various problems in government agencies so it is impossible to get stressed. Stress work can be interpreted as the pressure felt by employees because the job tasks they can not meet. In this research, stress variables that will be studied are: individual stressor (role conflict, work load, and career development), organizational stressor (organizational structure and leadership), so that later government agencies can identify which stress variables affect the employee performance and Handled.

The main problem in this research is whether the individual stressor and organizational stressor have an effect on the performance of the employees at the Office of Energy and Mineral Resources of South Sulawesi Province.

\section{LITERATURE}

According to Handoko (2000: 146) "stress is a condition of tension that affects the emotions, thinking processes and conditions of a person". Stress is also interpreted as the pressure, tension or unpleasant disturbance that comes from outside a person. Stress that is too large can threaten a person's ability to face the environment, which ultimately interfere with the implementation of his duties. In general, work stress is grouped into individual stressors and organizational stressors, as follows:

a. Individual stressors in the form of role conflict, role of role, workload, lack of career advancement and career development plan.

b. Stressor organization in the absence of participation, organizational structure, level of office, and lack of clear wisdom.

According to Wijono (2010: 122) job stress is a condition of subjective subjective appreciation of individuals that can be the interaction between individuals and work environments that can threaten and put pressure psychologically, physiologically, and individual attitudes.

According to Smith in Wijono (2010:119) the concept of work stress can be reviewed from several angles: first, work stress is the result of the workplace situation. Examples: noisy workplace situations and poor air ventilation. This will reduce employee work motivation. Second, work stress is the result of two organizational factors that are involvement in tasks and organizational support. Third, work stress occurs due to workload factors are also the ability to perform tasks. Fourth, it is the job responsibility factor. Finally, the challenge arises from the task. The conclusion of work stress is the result caused by the above factors. 
Stress indicator if not managed properly can cause depression, can not sleep, overeating, mild disease, not harmonious in friendship, decrease efficiency and productivity, excessive alcohol consumption and so on.

\section{Consequences of Work Stress}

Movement of the body's defense mechanism is not the only thing that arises from contact with the stressor. The impact of stress is numerous and varied. Of course, some of them are positive as self-motivation, hard work stimulation, increased inspiration to enjoy a better life. However, many stressors are intrusive and potentially dangerous. According to Cox in Gibson (1987: 207) has identified 5 types of potential consequences of stress impact. Cox's categories include:

1. subjective impact: anxiety, indifference, boredom, depression, fatigue, frustration, loss of patience, low self-esteem, nervousness, loneliness.

2. Behavioral effects: accidental tendencies, alcoholism, drug abuse, sudden bursting emotions, overeating, excessive smoking, conscientious behavior, nervous laughter.

3. Cognitive impact: inability to make clear decisions, poor concentration, short attention spans, very sensitive to criticism, mental obstacles.

4. Physiological effects: increased levels of sugar, increased heart rate and blood pressure, dryness in the mouth, sweating, enlarged pupils, hot body cold.

5. Organizational impact: absenteeism, employee turnover, low productivity, alienation from co-workers, unemployment, decreased attachment and loyalty to the organization.

These five types are not all-encompassing but are not limited to impacts where there is universal agreement and for that there is clear scientific evidence. They represent only some of the potential impacts that are often associated with stress. However, do not mean that stress always causes the impact as mentioned above.

Performance is basically a real behavior generated by each person as a work performance generated by employees in accordance with their role in the agency. To get a good performance of an employee in an organization must be able to provide facilities and infrastructure as a support in completing the work. Job performance is defined operatively as an employee effort to achieve goals through work productivity that is expressed in quantity and quality. This is achieved by running or perfecting the task efficiently and effectively within the organization. The dimensions of work performance that can be used as an example in performance appraisal can include quality or quality of work, interest in work, receiving direction, working knowledge, work effectiveness, positive attitude, attendance, and relationships with co-workers.

The term performance comes from the word job performance or actual performance (work performance or achievement actually achieved someone). Understanding performance (work performance) as described by Mangkunagera (2005: 67) is "the work in quality and quantity achieved by an employee in performing their duties in accordance with the responsibilities given to him".

Kusriyanto in Mangkunegara (2005: 9), defines "performance as a comparison of outcomes achieved with the role of labor unity of time (typically hourly)". Furthermore, according Faustino in Mangkunegara (2005: 9) definition of employee performance as "expression of output, efficiency and effectiveness often associated with productivity". 


\section{METHOD}

The method used is descriptive survey and explanatory survey method. The type of investigation in this study is causality. The unit of analysis in this study is all employees at the Office of Energy and Mineral Resources in Makassar.

Table 1 Concepts of variables, sub variables and indicators

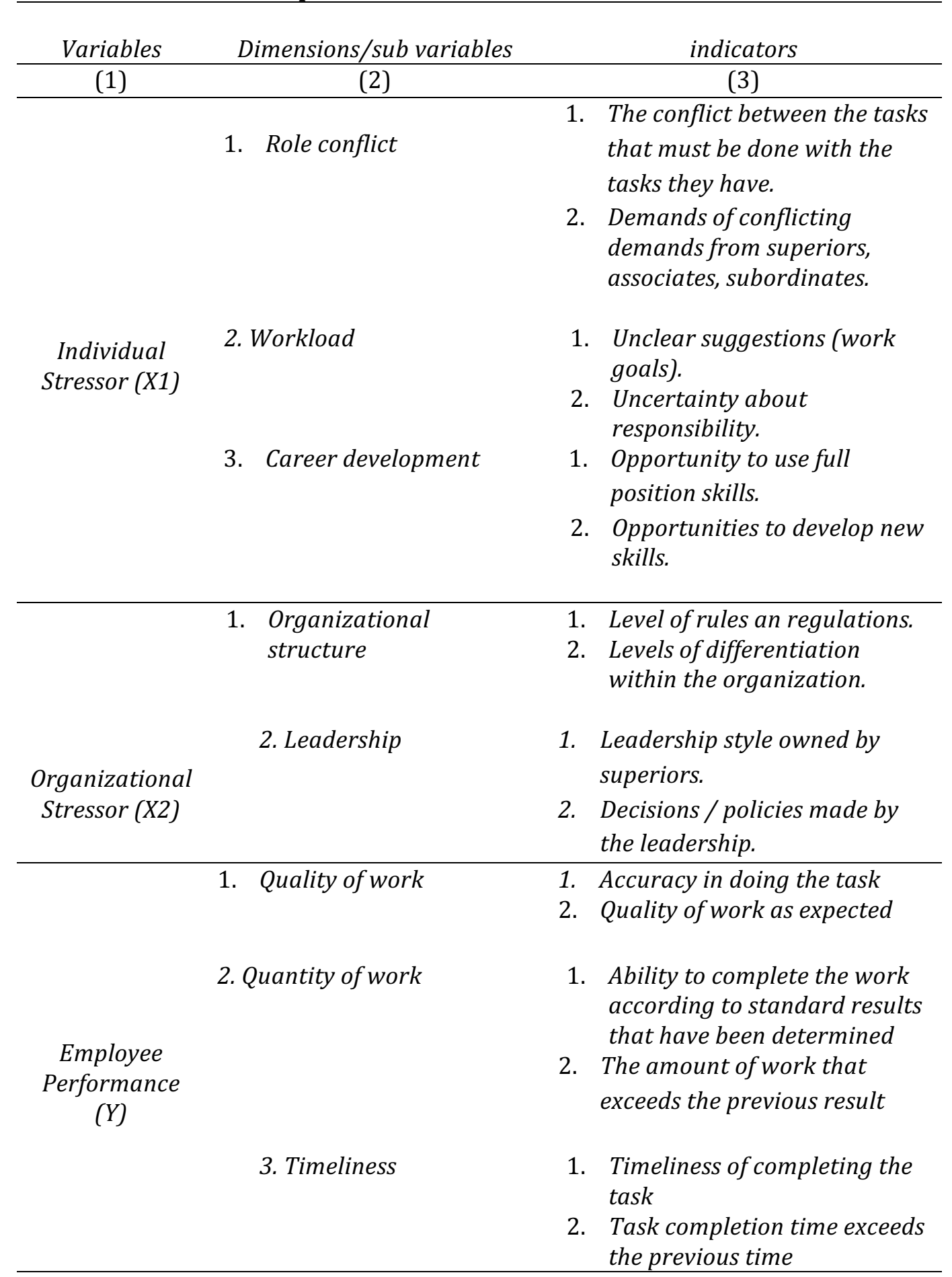

.Source: Derived from Gibson's theory (in Istijanto, 2010: 186-190), 2017.

By using Likert scale, the result of the research was analyzed by multiple linear regression analysis method with formulation

Where:

$$
\mathrm{Y}=\mathrm{a}+\mathrm{b} 1 \mathrm{X} 1+\mathrm{b} 2 \mathrm{X} 2+\mathrm{e}
$$


$\mathrm{Y}=$ dependent variable is performance

$\mathrm{X} 1$ = independent variable that is individual stressor

$\mathrm{X} 2$ = independent variable that is organization stressor

$\mathrm{a}=$ Constant value

$\mathrm{b}=$ regression direction coefficient

$\mathrm{e}=$ epsilon

\section{RESULT}

Analysis of the responses of respondents regarding individual stressors, organizational stressors and employee performance

Table 2: Respondents' Response to Individual Stressor Factors

\begin{tabular}{|c|c|c|c|c|c|c|c|c|c|c|c|}
\hline \multirow{2}{*}{ No } & \multirow{2}{*}{ Statement } & \multicolumn{10}{|c|}{ Respondents answer level } \\
\hline & & 5 & $\%$ & 4 & $\%$ & 3 & $\%$ & 2 & $\%$ & 1 & $\%$ \\
\hline (1) & $(2)$ & (3) & (4) & (5) & (6) & (7) & (8) & (9) & $(10)$ & $(11)$ & $(12)$ \\
\hline 1. & $\begin{array}{l}\text { I do not have enough } \\
\text { time to finish all my } \\
\text { work }\end{array}$ & 3 & 5.8 & 18 & $\begin{array}{c}34 . \\
6\end{array}$ & 11 & 21.2 & 18 & 34.6 & 2 & 3.8 \\
\hline 2. & $\begin{array}{l}\text { My workload is too } \\
\text { heavy for me }\end{array}$ & 1 & 1.9 & 16 & $\begin{array}{c}30 . \\
8\end{array}$ & 10 & 19.2 & 24 & 46.2 & 1 & 1.9 \\
\hline 3. & $\begin{array}{l}\text { I have to work super } \\
\text { fast in completing my } \\
\text { work }\end{array}$ & 5 & 9.6 & 12 & $\begin{array}{c}23 . \\
1\end{array}$ & 10 & 19.2 & 25 & 48.1 & 4 & 7.7 \\
\hline 4. & $\begin{array}{l}\text { My work often puts } \\
\text { me in an unhealthy } \\
\text { condition (eg a lot of } \\
\text { pollution, disease } \\
\text { outbreaks) }\end{array}$ & 1 & 1.9 & 12 & $\begin{array}{c}23 . \\
1\end{array}$ & 10 & 19.2 & 25 & 48.1 & 4 & 7.7 \\
\hline 5. & $\begin{array}{l}\text { I have an excessive } \\
\text { workload }\end{array}$ & - & - & 19 & $\begin{array}{c}36 . \\
5\end{array}$ & 10 & 19.2 & 20 & 38.5 & 3 & 5.8 \\
\hline 6. & $\begin{array}{l}\text { My work has a huge } \\
\text { amount of conflict } \\
\text { that demands me a lot }\end{array}$ & - & - & 18 & $\begin{array}{c}34 . \\
6\end{array}$ & 13 & 25 & 16 & 30.8 & 5 & 9.6 \\
\hline 7. & $\begin{array}{l}\text { I have trouble } \\
\text { communicating with } \\
\text { colleagues in this } \\
\text { office }\end{array}$ & - & - & 13 & 25 & 11 & 21.2 & 20 & 38.5 & 8 & 15.4 \\
\hline 8. & $\begin{array}{l}\text { I am required to } \\
\text { attend a very large } \\
\text { number of meetings. }\end{array}$ & - & - & 20 & $\begin{array}{c}38 \\
5\end{array}$ & 7 & 13.4 & 21 & 40.4 & 4 & 7.7 \\
\hline
\end{tabular}

\section{Source: primary data processed, 2017}




\section{Table 3: Response of respondents to factors causing the stressor organization}

\begin{tabular}{|c|c|c|c|c|c|c|c|c|c|c|c|}
\hline \multirow{2}{*}{ No } & \multirow{2}{*}{ Statement } & \multicolumn{10}{|c|}{ Respondents answer level } \\
\hline & & 5 & $\%$ & 4 & $\%$ & 3 & $\%$ & 2 & $\%$ & 1 & $\%$ \\
\hline$(1)$ & $(2)$ & (3) & $(4)$ & (5) & (6) & (7) & $(8)$ & (9) & $(10)$ & $(11)$ & $(12)$ \\
\hline 1. & $\begin{array}{l}\text { I get enough office } \\
\text { equipment to work }\end{array}$ & 10 & $\begin{array}{c}19 . \\
2\end{array}$ & 30 & $\begin{array}{c}57 . \\
7\end{array}$ & 4 & 7.7 & 8 & 15.4 & - & - \\
\hline 2. & $\begin{array}{l}\text { I have enough } \\
\text { support services to } \\
\text { carry out my work }\end{array}$ & 6 & $\begin{array}{c}11 . \\
5\end{array}$ & 30 & $\begin{array}{c}57 . \\
7\end{array}$ & 11 & 21.2 & 4 & 7.7 & 1 & 1.9 \\
\hline 3. & $\begin{array}{l}\text { I have difficulty } \\
\text { obtaining } \\
\text { consumables (such } \\
\text { as paper, clips and } \\
\text { balpoin) that I need } \\
\text { in my work }\end{array}$ & 1 & 1.9 & 13 & 25 & 8 & 15.4 & 26 & 50 & 4 & 7.7 \\
\hline 4. & $\begin{array}{l}\text { I do not know } \\
\text { exactly what the } \\
\text { agency expects } \\
\text { from me in relation } \\
\text { to the job positions } \\
\text { I receive. }\end{array}$ & 1 & 1.9 & 19 & $\begin{array}{c}36 . \\
5\end{array}$ & 13 & 25 & 17 & 32.7 & 2 & 3.8 \\
\hline 5. & $\begin{array}{l}\text { I feel that my boss } \\
\text { is so strictly } \\
\text { monitoring or } \\
\text { evaluating my } \\
\text { work }\end{array}$ & 3 & 5.8 & 17 & $\begin{array}{c}32 . \\
7\end{array}$ & 10 & 19.2 & 18 & 34.6 & 4 & 7.7 \\
\hline 6. & $\begin{array}{l}\text { The office tools I } \\
\text { need to run work } \\
\text { are often broken or } \\
\text { not working }\end{array}$ & 4 & 7.7 & 17 & $\begin{array}{c}32 . \\
7\end{array}$ & 13 & 25 & 18 & 34.6 & - & - \\
\hline 7. & $\begin{array}{l}\text { Targets and task } \\
\text { demands are too } \\
\text { high to burden my } \\
\text { duties }\end{array}$ & - & - & 15 & $\begin{array}{c}28 . \\
8\end{array}$ & 11 & 21.2 & 23 & 44.2 & 3 & 5.8 \\
\hline 8. & $\begin{array}{l}\text { I feel that I have no } \\
\text { role in any } \\
\text { decision-making }\end{array}$ & 2 & 3.8 & 10 & $\begin{array}{c}19 . \\
2\end{array}$ & 9 & 17.4 & 27 & 51.9 & 4 & 7.7 \\
\hline
\end{tabular}

Source: primary data processed, 2017 


\section{Table 4: Respondents Response Against Employee Performance Factors}

\begin{tabular}{|c|c|c|c|c|c|c|c|c|c|c|c|}
\hline \multirow[t]{2}{*}{ No. } & \multirow{2}{*}{ Statement } & \multicolumn{10}{|c|}{ Respondents answer level } \\
\hline & & 5 & $\%$ & 4 & $\%$ & 3 & $\%$ & 2 & $\%$ & 1 & $\%$ \\
\hline (1) & (2) & (3) & (4) & (5) & (6) & (7) & (8) & (9) & (10) & $(11)$ & (12) \\
\hline 1. & $\begin{array}{l}\text { The employee } \\
\text { completes the task } \\
\text { on time }\end{array}$ & 5 & 9.6 & 40 & 77 & 6 & 11.5 & 1 & 1.9 & - & - \\
\hline 2. & $\begin{array}{l}\text { This employee meets } \\
\text { the specified work } \\
\text { standards }\end{array}$ & 1 & 1.9 & 30 & $\begin{array}{c}57 . \\
7\end{array}$ & 20 & 38.5 & 1 & 1.9 & - & - \\
\hline 3. & $\begin{array}{l}\text { The employee is } \\
\text { serious about getting } \\
\text { the job done. }\end{array}$ & 2 & 3.8 & 32 & $\begin{array}{c}61 . \\
6\end{array}$ & 16 & 30.8 & 2 & 3.8 & - & - \\
\hline 4. & $\begin{array}{l}\text { This employee the } \\
\text { number of his work } \\
\text { fulfills the expected } \\
\text { demands }\end{array}$ & 1 & 1.9 & 22 & $\begin{array}{c}42 . \\
3\end{array}$ & 25 & 48.1 & 4 & 7.7 & - & - \\
\hline 5. & $\begin{array}{l}\text { This employee } \\
\text { shows a bad taste (eg } \\
\text { shy, or timid) if the } \\
\text { job is not finished }\end{array}$ & - & - & 30 & $\begin{array}{c}57 . \\
7\end{array}$ & 15 & 28.9 & 5 & 9.6 & - & - \\
\hline 6. & $\begin{array}{l}\text { This employee } \\
\text { shows the spirit or } \\
\text { strives to give the } \\
\text { best possible work. }\end{array}$ & 1 & 1.9 & 34 & $\begin{array}{c}65 . \\
4\end{array}$ & 12 & 23.1 & 5 & 9.6 & - & - \\
\hline 7. & $\begin{array}{l}\text { This employee does } \\
\text { not like to } \\
\text { procrastinate the } \\
\text { work to be done }\end{array}$ & 1 & 1.9 & 16 & $\begin{array}{c}30 . \\
8\end{array}$ & 22 & 42.3 & 9 & 17.3 & 4 & 7.7 \\
\hline 8. & $\begin{array}{l}\text { These employees } \\
\text { arrive on time at the } \\
\text { office }\end{array}$ & 2 & 3.8 & 28 & $\begin{array}{c}53 . \\
9\end{array}$ & 15 & 28.9 & 6 & 11.5 & 1 & 1.9 \\
\hline
\end{tabular}

\section{Source: primary data processed, 2017}

\section{RESULTS OF DATA ANALYSIS}

Based on the results of data analysis using computer program SPSS 21 for windows can be explained as follows:

The influence of work stress $(\mathrm{X})$ on employee performance (Y) 
Table 5: Results of SPSS Regression Coefficients

Coefficients ${ }^{a}$

\begin{tabular}{|c|c|c|c|c|c|c|}
\hline \multirow{2}{*}{\multicolumn{2}{|c|}{ Model }} & \multicolumn{2}{|c|}{$\begin{array}{l}\text { Unstandardized } \\
\text { Coefficients }\end{array}$} & \multirow{2}{*}{$\begin{array}{c}\begin{array}{c}\text { Standardize } \\
\mathrm{d} \\
\text { Coefficients }\end{array} \\
\text { Beta }\end{array}$} & \multirow[t]{2}{*}{$\mathrm{T}$} & \multirow[t]{2}{*}{ Sig. } \\
\hline & & B & $\begin{array}{l}\text { Std. } \\
\text { Error }\end{array}$ & & & \\
\hline \multirow{3}{*}{1} & (Constant) & 9.320 & 3.168 & & $\begin{array}{r}2.94 \\
\end{array}$ & .005 \\
\hline & $\begin{array}{l}\text { Individual Stressor } \\
\text { (X1) }\end{array}$ & .417 & .128 & .393 & $\begin{array}{r}3.25 \\
8\end{array}$ & .002 \\
\hline & $\begin{array}{l}\text { Organizational } \\
\text { Stressor (X2) }\end{array}$ & .375 & .122 & .372 & $\begin{array}{r}3.08 \\
1\end{array}$ & .003 \\
\hline
\end{tabular}

Source: data processed SPSS 21, 2017.

So the regression equation obtained is $\mathrm{Y}=9.283+0.417 \mathrm{X} 1+0.375 \mathrm{X} 2$.

Table 6: Results of SPSS Correlation Coefficient

\begin{tabular}{l|c|r|r|r|r|r|r|r}
\hline Model & $\mathrm{R}$ & \multirow{2}{*}{$\begin{array}{c}\mathrm{R} \\
\text { Square }\end{array}$} & $\begin{array}{r}\text { Adjusted } \\
\text { R Square }\end{array}$ & $\begin{array}{c}\text { Std. Error } \\
\text { of the } \\
\text { Estimate }\end{array}$ & $\begin{array}{c}\text { R Square } \\
\text { Change }\end{array}$ & $\begin{array}{c}\mathrm{F} \\
\text { Change }\end{array}$ & $\mathrm{df1}$ & $\mathrm{df2}$ \\
\hline 1 & & & & & & & &
\end{tabular}

Predictors: (Constant), Stressor Organization (X2), Individual Stressor (X1)

Dependent Variable: Performance (Y)

Source: data processed SPSS 21, 2017

Table 7: Results of T-SPSS Test (Partial Test)

Coefficients $^{\mathrm{a}}$

\begin{tabular}{l|r|r|r|r|r}
\hline Model & \multicolumn{2}{|c|}{$\begin{array}{c}\text { Unstandardized } \\
\text { Coefficients }\end{array}$} & $\begin{array}{c}\text { Standardize } \\
\mathrm{d} \\
\text { Coefficients }\end{array}$ & T & Sig. \\
\cline { 2 - 5 } & \multicolumn{1}{|c|}{ B } & \multicolumn{1}{c|}{$\begin{array}{c}\text { Std. } \\
\text { Error }\end{array}$} & Beta & & \\
\hline (Constant) & 9.320 & 3.168 & & 2.942 & .005 \\
$\begin{array}{l}\text { Individual Stressor } \\
\text { (X1) }\end{array}$ & .417 & .128 & .393 & 3.258 & .002 \\
$\begin{array}{l}\text { Organizational } \\
\text { Stressor (X2) }\end{array}$ & .375 & .122 & .372 & 3.081 & .003 \\
\hline
\end{tabular}

Dependent Variable: Performance (Y)

Source: data processed SPSS 21, 2017 
Table 8: SPSS Test Results F ANOVA ${ }^{\mathrm{a}}$

\begin{tabular}{rl|r|r|r|r|l}
\hline \multicolumn{1}{l|}{ Model } & \multicolumn{1}{c|}{$\begin{array}{c}\text { Sum of } \\
\text { Squares }\end{array}$} & Df & \multicolumn{1}{c|}{$\begin{array}{c}\text { Mean } \\
\text { Square }\end{array}$} & F & Sig. \\
\hline \multirow{3}{*}{1} & Regressio & 307.587 & 2 & 153.794 & 17.805 & $.000^{\mathrm{b}}$ \\
& $\mathrm{n}$ & & & & \\
& Residual & 423.240 & 49 & 8.638 & & \\
& Total & 730.827 & 51 & & & \\
\hline
\end{tabular}

Dependent Variable: Performance (Y)

Predictors: (Constant), Stressor Organization (X2), Individual Stressor (X1)

Source: Data processed SPSS 21, 2017

\section{DISCUSSION}

The results of this study showed that work stress has an effect on the performance of employees of the Office of Energy and Mineral Resources of South Sulawesi Province. The relationship between individual stressors and organizational stressors on employee performance has a very strong relationship. This means that if individual and organizational stressors increase then employee performance will decrease.

Individual stressors have the most dominant influence on employee performance. Individual stressors can be caused by several things such as role conflict such as the conflict between tasks to be performed with tasks, workload such as uncertainty of suggestions (work goals) and career development such as the opportunity to use full position skills. Individual Stressor at the Office of Energy and Mineral Resources of South Sulawesi Province has a significant influence on its performance. This is indicated by the existence of individual stressors causing many employees who are not motivated to work and complete tasks on time so that performance is reduced.

Organizational stressors also affect employee performance even if the effect is not as big as the effect of individual stressor. Organizational stressors can be caused by several factors including the organizational structure that includes the level of rules and regulations and the level of different in the organization and also caused by leadership that includes leadership styles owned by superiors and also decisions / policies made by the leadership.

\section{CONCLUSION/RECOMMENDATION}

The conclusions and suggestions in this study are as follows:

Variables of stressor and organizational stressors together have a significant influence on the performance of employees at the Office of Energy and Mineral Resources South Sulawesi Province.

The individual stressor variable as the most dominant factor influenced the performance of employees of the Office of Energy and Mineral Resources of South Sulawesi Province. Government agencies should pay more attention to individual stressor factors and organizational stressor factors because these two factors can have an effect on employee The agency should pay extra attention to employees who are in dusty, noisy, hot and timeconsuming work conditions that make employees more vulnerable to stress or stress.

The government agencies need to pay attention, as well as to maintain the stre work stability caused by individual factors and organizational factors through activities that motivate employees such as recreation, out bond, relaxation time, work hour division, communication 
channels such as discussion forums and openness of leaders who ultimately have implications On optimal employee performance.

\section{References}

Bernardin, H. John \& Joice E, A. Russel.1993.Human Resource Management, Mc. Graw-Hill, Inc.

Gibson, Ivancevich.1987.Organisasi Proses Struktur Perilaku. Edisi Lima, Jakarta:Erlangga

Hasibuan, Malayu.2010.Manajemen Sumber Daya Manusia.Jakarta: Bumi Aksara

Handoko, Hani.2005.Manajemen Sumber Daya Manusia.Bandung: BPFP

Hermita.2011.Pengaruh Stress Kerja Terhdap Kinerja Karyawan Pada PT. Semen Tonasa (Persero) Pangkep.Tidak Dipublikasikan

Iswahyu, Hartati.2005.Pengaruh Kesesuaian Kompetensi dan Motivasi Kerja Terhadap Kinerja Pegawai pada Sekretariat Daerah Kabupaten Malang, Eksekutif, Jurnal Manajemen Bisnis, Vol. II, No.1

Malayu, S.P. Hasibuan, 2006.Manajemen Sumber Daya Manusia. Edisi Revisi, Cetakan Kedelapan, Jakarta: Bumi Aksara.

Mangkunegara, Anwar Prabu.2005. Manajemen Sumber Daya Manusia Perusahaan. Bandung: PT. Remaja Rosolakarya Offset.

Moh. As'ad.2001.Psikologi Industri: Edisi Keempat. Yogyakarta: Liberty

Munandar Ashar Sunyoto, 2001.Psikologi Industri dan Organisasi.Jakarta: Universitas Indonesia

Raharjo, Dwi Sihono.2005.Kinerja Karyawan Survei di Bank Negara Indonesia dan Bank Central Asia.Jurnal Manajemen, Th IX/01/Feb/2005,Hal 19-26

Singaribuan, Masri \& Sofian Effendi, 1995. Metode Penelitian Survai.Jakarta: LP3ES

Sugiyono, 2007.Statistika Untuk Penelitian.Bandung: Alfabeta

Swasto, B.2003.Pengembangan Sumber Daya Manusia.Edisi Kedua, STIE YKPN, Yogyakarta

Tommy Meilitza.2009.Pengaruh Stress kerja terhadap kinerja karyawan ATC Makassar Air Traffic Service Center PT. Angkasa Pura I (Persero).Tesis Fakultas Ekonomi Universitas Hasanuddin Makassar.tidak Dipublikasikan

Umar, Husein.2004. Riset Sumber Daya Manusia Dalam Organisasi.Jakarta: Gramedia Pustaka Utama

Umar, Husein.2005.Riset Sumber Daya Manusia Dalam Organisasi, .Jakarta: PT SUN

Wijono, Sutarto.2010.Psikologi Industri dan Organisasi.Jakarta: Kencana Prenada Media Group www.esdmsulsel.com 